\title{
"ARE YOU ONE OF US?" \\ POINTS OF SOCIAL EXCLUSION AMONGST YOUTHS OF DIVERSE RELIGIOUS GROUPS IN INDONESIA
}

\author{
Roosalina Wulandari'; Elizabeth Kristi Poerwandari \\ ${ }^{1}$ International Business Management Program, Management Department, \\ BINUS Business School Undergraduate Program, Bina Nusantara University \\ Jl. Jl. Hang Lekir I No. 6, RT. 1/RW. 6, Senayan, Jakarta Pusat 10271, Indonesia \\ ${ }^{1,2}$ Faculty of Psychology, Universitas Indonesia \\ Jl. Lkr. Kampus Raya Jl. Mawar No. 53 8, Pondok Cina, Depok, Jawa Barat 16424, Indonesia \\ ${ }^{1}$ rwulandari@binus.edu; ${ }^{2}$ elizabeth.kristi@ui.ac.id
}

Received: 09 ${ }^{\text {th }}$ February 2021/ Revised: $21^{\text {st }}$ June 2021/ Accepted: $23^{\text {rd }}$ June 2021

How to Cite: Wulandari, R. \& Poerwandari, E. K. (2021). "Are you one of us?"

Points of social exclusion amongst youths of diverse religious groups in Indonesia. Humaniora, 12(3), 243-253. https://doi.org/10.21512/humaniora.v12i3.7036

\begin{abstract}
Deriving from basis of the social identity theory and its development, the research aimed to explore the points of exclusion and how individuals and groups perceived themselves as experiencing victimhood of social injustice. The rise of intolerance in Indonesia was alarming and threatened the diversity and inclusivity of the nation. Throughout several political milestones such as gubernatorial and presidential elections, identity had been used as one of the most efficient ways to segregate and discriminate against people belonging to different groups. Applying a qualitative approach, data were mined from two focus group discussions of university student respondents with various religious and ethnic backgrounds representing the majority and minority groups in Indonesia. Groups sessions were strictly differentiated between majority and minority representatives to minimize the risk of potential conflict. The findings suggest that both groups' initial perceptions towards members of outgroups are heavily influenced by transferred stereotypes and prejudices from the older generations. While the majority group struggles to counter the prejudices and perceived victimhood through direct exposure, the minority group, on the other hand, takes language into account as a subtle gesture of exclusion.
\end{abstract}

Keywords: social exclusion, religious groups, Indonesian youths

\section{INTRODUCTION}

Interest in the notion of identity has grown exponentially since the era of postmodernism to the mid-1990s (Hogg, Abrams, \& Brewer, 2017; Huddy, 2015). Social scientists, in particular, social psychologists, sociologists, and anthropologists, have contributed to the idea of identity from different approaches and perspectives (Huddy, 2015). An explanation of the social identity approach (Hornsey, 2008), mainly introducing the social identity theory and self-categorization theory, is able to answer the robust debate on the development of the social psychological theory and research during the 'crisis of confidence' in the late 1960s and early 1970s. The 1980s period witnessed a massive escalating number of studies and publications on social identity and became paramount to the renewal of social psychological research on the group process (Hogg et al., 2004). In the recent rise of identity politics around the globe, Huddy (2015) has argued that the social identity theory (SIT) has become a significant framework to be incorporated in empirical studies as it addresses issues that are of interest, such as intergroup conflict, conformity to group norms, collective actions, and promoting factors of self-categorization and others into groups. 
The social identity theory is very relevant to the current notion of the development of identity politics in Indonesia. The recent rise of intolerance as a result of identity politics amongst religious and political groups in Indonesia has become alarming. The 1998 riot and the fall of the New Order regime opened the door to democracy (McCoy, 2013) and accommodated social vigilantism that promotes intolerance and discriminative behaviors (Menchik, 2014). The rising intolerance between the Muslim majority groups and the other groups has created concerns over the threat towards liberalism and religious pluralism (McCoy, 2013). It was reanimated during Jakarta's gubernatorial election in 2017 by means of religious identity politics. Recent findings from nationwide surveys conducted by CSIS (2017) have exposed distressing results on intolerance differences of ideas, values, and beliefs. The findings are echoed by a PPIM-UIN survey (2017) displaying results on the latent risks of intolerance and how threats are perceived by the Muslim majority groups, and in return, manifested in perceived victimhood and negative sentiments towards different group members.

As elaborated by Menchik (2014), the Indonesian state of religiosity is coined as Godly Nationalism, which defines a state with a national identity that is exclusively religious but does not particularly refer to any religion. Since the demand is for the citizens to have faith in God without enforcing a specific religion, preserving this national identity must involve privileges to some beliefs and not tolerate forms of deviations that can be perceived as threats to the religious worldview favored. The phenomenon of intolerance is also amplified by the growing spirit of religious purification movements that leaves more room for exclusions and eschew any forms of innovation and engagement within a cultural context.

Since Tajfel and Turner have introduced the term 'social identity' as the meaning an individual gives to oneself and how individuals perceive themselves in a group or groups, the perspective of social identity is intended to be viewed as an analysis of interactions related to group membership and group processes that focuses on the relationship between the personal self and the collective self (Hogg et al., 2004). A further explanation of the social identity theory emphasizes how human interactions fall into the range of being purely interpersonal to purely intergroup (Hornsey, 2008). Being the representative of their groups will result in individual identities being overshadowed by groups' membership salience. It is then argued that the dynamic of the interpersonal-intergroup interactions will result in shifts as to how people perceive themselves and others as 'us and them' (Hornsey, 2008; Onorato $\&$ Turner, 2004). As elaborated by Hogg et al. (2004), the idea of a social group is a collection of more than two people who share the same social identity that constitutes the same definition of who they are, the attributes they have in common, and how they relate and differ themselves from specific outgroups. It is also emphasized that personal identity has little contribution to the group process, although group life might significantly contribute a context to form personal identities, such as friendships and enmities.

Previous studies have also shown how identity levels affect human behavior by experimenting with non-conflicting race groups in the UK (Chowdhury, Jeon, \& Ramalingam, 2016) and how national identity is perceived as a political identity and influenced by social interactions with other national identities. The research claims to offer an extension of understanding into how social interactions contribute to collective identity (Stoeckel, 2016). The main contribution of the research has resulted in a more refined theory on the mechanism of how social interactions might lead to identity change and concluded by stating that the intergroup contact situation must meet certain criteria to contribute to a shared identity (Stoeckel, 2016). The finding resonates with how people make efforts to promote or protect their own group status and prestige as they perceive a group evaluation as a selfevaluation. In the notion of a salient group, it represents the collective self (Hogg et al., 2004). Furthermore, since the social identity theory's motivational stress is on status competition among groups, the emphasis is not on uniformity and assimilation but on recognizing differences between in-group and outgroup members (Hogg, Abrams, \& Brewer, 2017).

Recent studies have employed this framework to identify how intergroup interactions exist and are applied in the political field and the presence of conflict, the resolved and unresolved ones. Several studies have highlighted addressing the construct of group identities (a natural group, a minority group of religious identity, and political identity in relation to ideological commitment) in the encounter of a conflict context. In the light of increased public hostility towards Muslim minorities in Europe, identity conflict and compatibility among Europeanborn Muslims are examined (Fleischmann, Phalet, \& Swyngedouw, 2013). The research has contributed to the understanding in a sociopolitical context of minority identification and pointed out the role of the majority groups to value and acknowledge the minority identities. In the context of intractable conflict, many studies have employed different approaches to be able to capture the individual and collective identity dynamics. Several studies refer to the conflict context, showing findings of how the notion of group identity salience and how group members are more likely to display prejudice and aggression towards outgroup members when encountered with an intergroup threat (Merrilees et al., 2013).

A different perspective on intergroup contact is offered by Voci et al. (2015). Their research has inspected the association between intergroup contact and intergroup forgiveness in the presence of intergroup conflict and in-group identification. Furthermore, the research claims that the result of a friendship contact is positively associated with forgiveness, in contrast to how conflict experience and group identification are negatively associated with forgiveness (Voci et al., 
2015). The argument is that engaging psychologically with past political violence could result in the development of more positive intergroup relations and facilitate the political society's recovery. It is believed that intergroup forgiveness is feasible when made central and as an objective of intergroup contact in the form of friendships.

Resonating that intergroup forgiveness is the quest for resolution and peace, various studies focus on intractable conflict settings. As values and beliefs are part of the identity attributes, studies in intractable conflict settings try to examine socio-psychological factors contributing as barriers to peacebuilding efforts. As reported in another research, a conclusion is drawn on how an individual's openness to conflict resolution is influenced by one's general worldview that includes universalistic values, traditional values, and conformist values (Halperin \& Bar-Tal, 2011).

Indonesia is not immune to conflict as the nation's diversity includes religions, ethnicities, languages, dialects, traditions, et cetera. Naturally, people see differences as a way to exchange information, learn about cultures, and develop empathy and understanding. However, the inherited stereotypes and prejudices that have prevailed since the Dutch colonial era should not be left unaccounted for. The politics of divide et empera, translated as 'divide and conquer', contribute to creating perceived threats towards each other. Hence, this research seeks to investigate how members of different groups identify each other and categorize those perceived as members of or threats to their groups.

In an effort to buffer themselves from different views that challenge theirs, people shield themselves by doing selective exposure and accessing information that supports or resembles their worldviews and ideologies (Barberá et al., 2015). Consequently, when encountered with different alternative views, people can display strong reactions of discrediting and derogating those who think differently, since people tend to perceive their understandings of the world as better and more correct than others. Similarly, Skitka (2010) has stated that people with strong moral convictions prefer to distance themselves from those considered attitudinally divergent from others, therefore, have little need to revert to their peers to seek the 'right answer'. This clearly defines a display of moral superiority to themselves and those with similar viewpoints. Collectively, it establishes a strong urge to secure and promote ideological integrity and superiority (Hogg, Kruglanski, \& Bos, 2013).

Thus, the question of why people display intolerance and several factors have emerged as promoting intolerance. Personal uncertainty that leads to the need for closure has concurred (Brandt \& Reyna, 2010; Jost, 2006; Jost et al., 2003; Kruglanski et al., 2006). People usually feel uncertainties towards many things like their values, attitudes, beliefs, religions, the future, and many more as constituted in their worldviews. People also do not like their beliefs or ideas to be challenged or countered by others (Brandt,
2017; Brandt \& Van Tongeren, 2017; Jacks \& Cameron, 2003; Saucier \& Webster, 2010) since they believe that their worldviews are the correct ones or more superior than others. Hence, any challenges to their held beliefs or worldviews are perceived as threats to their very self and identity (Stephan \& Stephan, 1985; Stephan, Stephan, \& Gudykunst, 1999).

When faced with uncertainty and the need to protect oneself, grounding one's beliefs and worldviews with like-minded people helps reduce anxiety and at the same time reinforces their worldviews collectively (Bos et al., 2005). In terms of protecting their beliefs, people can also avoid and isolate themselves from views that dissent from theirs and negate strongly towards those who think differently. Due to this motivation to protect and promote the ideological integrity derived from the feeling of moral superiority and in the hardships of uncertainty, people will display the need for closure by indicating close-mindedness and intolerance (Hogg, Kruglanski, \& Bos, 2013). When the need for closure is high in the presence of uncertainty, extreme groups and ideologies might offer the means of reducing anxiety. Extreme groups and ideologies, typically reflected in religious and political fundamentalism, display intolerance in the forms of the rejection of scientific advancements (Scheufele et al., 2009), prejudice toward a variety of outgroups (Hunsberger \& Jackson, 2005), and violence (Ginges, Hansen, \& Norenzayan, 2009).

This room for exclusion and the sense of 'us versus them' segregates people into many levels of categorization. Hence, bearing the abovementioned phenomenon, this research aims to explore these research questions: (1) How do Indonesian people selfcategorize and exclude others who are perceived as being members of different groups? (2) How does this self-categorization promote intolerance in Indonesia?

The research highlights the attention to the perception of intolerance amongst youths in Indonesia and analyze the phenomenon based on the perspectives of social identity development, how individuals categorize themselves into groups, and how religious intolerance influences that categorization process. Findings will help collective efforts to strategize on promoting tolerance and inclusivity as means of peacebuilding initiatives.

\section{METHODS}

The research aims to understand how Indonesian youths, both from the majority and minority groups, perceived intergroup relations and their contributions to the increase in religious intolerance in Indonesia by using a thematic analysis from the data mined through focus group discussions. As one of the cores and fundamental approaches to qualitative research, a thematic analysis is understood as an identification and analysis method that can report patterns and themes from data. A thematic analysis offers flexibility for the data collection and analysis process, and it can 
generate insights along with underlining key concepts, which helps with the interpretation of the data (Braun \& Clarke, 2006). The research employs a thematic analysis due to its ability to offer flexibility and insights. Purposive sampling is also conducted, and data are gathered from two focus group discussion sessions for each of the majority and minority groups. Sessions are strategically separated in an effort to be able to collect more sensitive data without the participants engaging in potential tension and conflict with members of different groups.

The recruited participants are university students currently residing in Jakarta, the melting pot of Indonesia, with various backgrounds. The recruitment of the respondents varies based on their religious and ethnic backgrounds. Efforts are also made to ensure that both genders are balanced. The respondents are then categorized as part of the majority group if they are Muslims and descendants of one of the dominating ethnicities in Indonesia, while those categorized into minority groups are non-Muslim respondents and descendants of non-dominating ethnicities. Although the research is unable to recruit participants with these particular additional criteria, the recruitment process also considers extensions to certain denominations (e.g., Shia, Ahmadiyah, and Sufism for Muslims) and also potentially different sexual orientations.

The finalized recruited respondents are then categorized into majority or minority groups that fit with their selection criteria. This categorization is designed to ensure that the focus group discussions are conducted in separate sessions between the majority and minority groups in an effort to accommodate more freedom and minimize the risk of tension when exploring experiences that are deemed sensitive and/ or perceptions towards different groups members.

The research collects information from two focus group discussions. Each session is conducted separately for the representatives of the majority and minority groups. All the majority and minority groups are designed to have separate sessions due to the potential tensions and conflicts that could be triggered during the discussions. As a catalyst, a very general and broad question such as, "Please tell me about your experiences interacting with people from different religions and/or ethnicities from you", is asked. An exploration then followed by asking probing questions: (1) Can you please elaborate further on that experience? (2) Have you ever been discriminated by or discriminated against others when interacting with people from different groups? (3) Have you ever had a positive contact experience with people from different groups? (4) What do you suggest should be done for different groups to coexist? (5) Do you have any suggestions on how people can be more open-minded towards each other?

The length of each session is managed at two hours maximum, including a debriefing process at the end of each session. A debriefing is mandated as exploring the topic could recollect memories of inconvenient experiences, tensions, and contradicting opinions and perceptions. The points of the discussions are focused on, but not limited to, positive and negative contact experiences with outgroups, whether the experiences are influenced by pre-notions of stereotypes and prejudices, and how they perceived those contact experiences. The respondents are also invited to explore ways to promote tolerance and inclusivity in an effort to be able to coexist peacefully in a diverse nation. The focus group discussions are recorded (with the consent of the participants) and later transcribed for analysis purposes.

Data are coded and analyzed to look for consistency of emerging themes. From the focus group discussion data, the initial analysis identifies several perspectives that would be explored deeper. The themes that offer a formation of the narratives are: (1) Perceived threats and victimhood for both majority and minority groups towards each other. (2) Emerging points of exclusion: ethnicities, religion, political ideologies, interests, language, dialect, lifestyle (vegetarian). (3) Many of the stereotypes, prejudices, and traumas were passed down, but the younger generation is willing to counter them.

The selected participants for the majority groups represent Javanese, Sundanese, Palembangese, and Padangese ethnicities and all are Muslims. The minority consists of Chinese-Indonesian descendants of various religions, and they are prone to the exposure of stereotypes and prejudices. The combination of their ethnicity and non-Moslem religion create a double minority status in Indonesia. Further details of the respondents are summarized in Table 1. Despite being given a chance to terminate their involvement whenever they no longer feel comfortable, all the participants manage to complete the entire session.

Table 1 Selected Respondents of the Focus Group Discussions (Aliases are Used to Ensure Confidentiality)

\begin{tabular}{lll}
\hline & Aliases & Brief Background \\
\hline MAJORITY & Tas, female & She came from a homogeneous Muslim background, spent formative years in an \\
GROUPS & & Islamic education institution. The university level was her first exposure to different \\
& group members, and she was questioned for her decision to study in an institution \\
& where she was exposed to different group members, in particular, Indonesian \\
& Chinese descendants. \\
\hline
\end{tabular}


Table 1 Selected Respondents of the Focus Group Discussions

(Aliases are Used to Ensure Confidentiality) (Continued)

\begin{tabular}{|c|c|c|}
\hline & Aliases & Brief Background \\
\hline & Nor, female & $\begin{array}{l}\text { She has a very similar background with Tas as they both came from the same } \\
\text { previous Islamic education institution. She sees exposure to diversity as a positive } \\
\text { opportunity to exchange knowledge and openness. }\end{array}$ \\
\hline & Far, female & $\begin{array}{l}\text { She went to an international high school and has been experiencing exposure since. } \\
\text { She has experienced being a minority in an interfaith peer group and considers } \\
\text { herself as a moderate Muslim. }\end{array}$ \\
\hline & Ims, male & $\begin{array}{l}\text { He came from a traditional conservative Minangese family that transferred } \\
\text { a stereotype and prejudice towards the Indonesian-Chinese descendants. He } \\
\text { experienced exposure at the university level. }\end{array}$ \\
\hline & Muh, male & $\begin{array}{l}\text { He grew up in a community that exercises Islamic fundamentalism and discourages } \\
\text { intimate social contact with different group members. }\end{array}$ \\
\hline & Aly, female & $\begin{array}{l}\text { She is a Muslim woman who constantly relocated with her family as a child, and } \\
\text { currently lives in a neighborhood dominated by Indonesian Chinese descendants. } \\
\text { Her initial contact was positive, but then it changed after the political conflict of } \\
\text { Jakarta's Governor in } 2016 \text {. }\end{array}$ \\
\hline \multirow[t]{5}{*}{$\begin{array}{l}\text { MINORITY } \\
\text { GROUPS }\end{array}$} & Rez, female & $\begin{array}{l}\text { She is a Catholic by birth with a mixed family background of diverse faiths and } \\
\text { ethnicities. She is accustomed to being tolerant and exercising openness. She is a } \\
\text { mixed-ethnicity of Javanese and Indonesian-Chinese descendants. }\end{array}$ \\
\hline & Fan, female & $\begin{array}{l}\text { She is an Indonesian-Chinese descendant, Catholic, and living in a Muslim- } \\
\text { dominated area. }\end{array}$ \\
\hline & Wen, male & $\begin{array}{l}\text { He is a Christian and Indonesian-Chinese descendant who was exposed to } \\
\text { stereotypes and prejudices transferred by his parents, and to members of different } \\
\text { groups (Muslims who work for the family household) since his formative years. }\end{array}$ \\
\hline & Ric, male & $\begin{array}{l}\text { He is a Buddhist and Indonesian-Chinese descendant who went to a Christian } \\
\text { school. He was exposed to the local Batak ethnicity but interactions were limited } \\
\text { by the local languages used (Bahasa Indonesia was used by the Batak ethnicity and } \\
\text { Hokkien was used by the Indonesian-Chinese descendants). }\end{array}$ \\
\hline & Lev, female & $\begin{array}{l}\text { She is a Catholic and Indonesian-Chinese descendant who went to a Christian } \\
\text { school and never experienced discrimination due to her ethnicity. Despite the } \\
\text { exposure to different faiths in school (Christianity, Catholicism, and Buddhism), the } \\
\text { demographics of the students and the surrounding community were dominated by } \\
\text { Indonesian Chinese descendants. }\end{array}$ \\
\hline
\end{tabular}

\section{RESULTS AND DISCUSSIONS}

How perception formatted, to begin with, is explored and assessed to see how extensive the influences of transferred values are when in contact with members of different groups. The stereotypes and prejudices are reflected in the values transferred by older family members of many respondents. Some strong stereotypes and prejudices are displayed by communities of religious fundamentalists. They allow social contact with members of different groups but restrain themselves from intimate contacts such as shared living space and meals. This point is specifically highlighted by Muh.

“.. from where I come from, Serang Banten, Islamic fundamentalism is exercised. When interacting with non-Muslims, we are not allowed to drink from the same glass or stay overnight and share a bed. I actually wonder until today, is it really necessary to have such restrictions? I don't know, please correct me if
I'm wrong. There is a hadith or verse that says we cannot drink or sleep with those who have different faiths from us."

This particular restriction is also supported by Ims, whose knowledge about this contact limitation is directly transferred from his parents. The concern is because many non-Muslims own dogs, and dog saliva is considered unclean and not kosher for Muslims.

"My parents did mention the same thing to me. The perception was because non-Muslims usually own dogs, eat pork, et cetera. So, parts of their houses and some of their eating utensils could be contaminated."

Similar to the majority group, the respondents of the minority group also experience transferred stereotypes and prejudices from their parents and the older generation. As Wen has stated:

"Many of the stereotypes that I know of, I did not learn them from my interactions with other 
communities. Instead, the stereotypes were subtly introduced by my parents. At one point during the election period, and as we watched the news with our parents, they would make remarks that would seem to corner specific groups usually Muslims."

What also needs to be highlighted is that not only stereotypes and prejudices are transferred between generations, but also collective memories of traumatic experiences. Ric has mentioned how he perceives masses conducting prayers together as a threat to his safety as a member of a minority group.

"For example, last week when they conducted a mass prayer at GBK (Jakarta's largest sports stadium), it scared us and made us stay away from the area. We felt threatened as members of minority groups. If we were on the street, [we fear] they will suddenly look at us and say 'Oh this one is Tionghoa [Indonesian-Chinese descendant]' and they will harass us. We feel threatened."

Ric's statements are relevant when referring to the traumatic experiences that the Indonesian-Chinese descendants experienced when the 1998 riots broke out in Jakarta during the fall of Suharto's New Order regime. The riots specifically target the IndonesianChinese descendants, as they are violently attacked.

However, despite the fact that many of the respondents from both the majority and minority groups come from a homogenous background, they endure the strong presence of stereotypes and prejudices. Many of them deliberately chose to see things from different perspectives. Some respondents from both groups have reported how they categorize themselves as more moderate and liberated than their older generation. Some of them are self-proclaimed it.

"The moment I joined Binus [university], it felt like I found my people. It's like a melting pot, and many of us never questioned our race and religion." [Far]

"I am not very religious. I have no problems if they are very religious. I don't have problems if they are very traditional. As long as they are not patronizing other people's perspectives, it's fine. Many of my friends are like that, and they know that I am not into religion, but they're chill about it. It's like my religion is for me, and yours is for you." [Lev]

Furthermore, some others choose to counter the stereotypes and prejudices introduced to them by exercising direct contact with the different groups.

"Socializing with people with different mindsets is still important, even very important. Without it, what makes us different than the other narrow-minded groups?" [Wen]
"At the beginning of my first year at Binus [university], I hanged out with non-Muslims. Over time, I learned that both groups have misperceptions towards each other. For example, I am a Minangese who thought the [Indonesian-] Chinese [descendants] were getting special treatments in economic and trade policies. This might be due to the perception of my grandfather who was born in the Soeharto era, and at that period of time, some [Indonesian-] Chinese [descendants] conglomerates did get special treatments. But when I interacted with them, it turned out they also had a perception that the native ethnic [Minangese and others] groups were the ones getting privileges. Despite the fact that some of these [Indonesian-] Chinese [descendants] did receive special treatments, many of them also experienced oppression.” [Ims]

Positive contact and openness also help the respondents to develop empathy and understanding. Many of the respondents see that exposure to other groups helps them to see things from other people's points of view.

"My experience of interacting with people from different religious groups, ethnic groups, and native languages at the university has really opened up my mind. It is an entirely new experience, because apparently there is a bigger world out there than school. Here, we can share and exchange information so that we understand better about different practices of religions." [Nor]

"There are many people of different religions, and I learned to be more accepting. If we only stay in our majority bubble, it will be difficult for us to understand and accept differences." [Far]

"I went to a high school that was not a faithbased school. I became friends with people from different religions and never experienced any type of discrimination. So, we got the opportunity to learn from each other." [Rez]

Hence, it is sufficient to state that direct contact and exposure as a gesture of openness is a means that the respondents chose to shift their perspectives about the previous stereotypes and prejudices transferred in their families and communities.

An emerging theme that displayed conflict between groups of local ethnicities and ethnic groups from other provinces in Indonesia is related to perceived victimhood. The conflicts are political, where local ethnic groups strive for superiority and domination.

"This is according to my perception. Each 
of the ethnic groups has their own ego. The ethnic groups that are not from this area are very competitive, while the local ethnic groups hold on to the pride of their homeland. This is my homeland; don't act like you own it. That's what we feel; the newcomer ethnic groups as the minorities dominate in our homeland." [Muh]

A sense of entitlement is strongly displayed that the local ethnic groups should be superior and dominate the newcomer ethnic groups in their homeland. Otherwise, it will be perceived as a threat to their identity and superiority. Other concerns about being a minority are also displayed by the majority groups. Tas has highlighted how she is shown concern by the older generation in her family.

"But what made me realize and open my eyes was their ways of pointing out the differences. For instance, people around me asked, 'Sorry, is your university dominated by IndonesianChinese descendants?" [Tas]

The concerns subtly suggest that different groups, Indonesian-Chinese descendants, in particular, are perceived as threats to their identity and come from pre-existing stereotypes and prejudices. It is especially when the concerns are from a homogenous community with limited interactions with different group members.

Past studies about tolerance still leave plenty of room for exploration. The research tries to contribute to more factors of intolerance that might indicate layers of exclusion. Initial findings have hinted that language might need further exploration as a point of exclusion that might not necessarily create conflict but potentially segregate and play a part in selfcategorization. Some of the points of exclusion that emerged from the respondents include ethnicity, religion, language, political ideology, religious attire, religious lifestyle, and contact with a different group.

As reported by many respondents from both the majority and minority groups, ethnic identity is highly salient. One of the main values transferred by the older generation is not getting involved in an intimate social commitment, such as marriage. Respondents from the minority group dominated by Indonesian-Chinese descendants have stated that their older generation emphasizes intra-ethnic marriage arrangements. Interfaith marriages are also not encouraged, however still tolerable compared to inter-ethnic marriages. Hence, ethnic salience as an identity plays a greater role in the point of exclusion, followed by religion.

"In Medan, people can be highly discriminative. There are limitations by saying that you have to marry someone from your own ethnic group. Religion-wise, well if you are from the same ethnic group, most likely you share the same religion. So, that is the restriction from the family." [Ric]
"I am required to marry someone of my own kind. I have an aunt that was reluctant to send her child to study at a public university because she feared that her child might date a Muslim. As for my parents, the demand is not only based on ethnicity but also religion. So, I must marry a Catholic who is also an Indonesian-Chinese descendant. They really don't appreciate a conversion of faith, even if it is as close as a Catholic converting to become a Christian." [Lev]

"From my father's family's side, it is totally unacceptable. My father used to date a nonChinese and a Muslim, and my grandmother went against the relationship. It is a similar thing with my mother's family's side. Although there are some family members who are married to people from different ethnicities, it is still without the consent of the family." [Wen]

"That happened to my brother. We're a Catholic family, but my brother married a Christian Indonesian-Chinese descendant woman and converted. My grandparents were not happy about him converting. They think men should not follow their wives' religion. So that was it, but it happened already. Still, my family puts ethnicity as a priority requirement to search for a spouse." [Fan]

The next intimate social contact highlighted in the transferred values by parents and the older generation is friendship. The respondents from both groups have reported restrictions and limitations on how they are allowed to socially interact with members of different religious groups. Wen has said that his parents always question his friends' religion and usually advise him not to be too close with friends from different religious groups. Muh and Ims have similarly reported instructions from their parents on cues of how to interact socially with friends from different religious groups. Specifically, Muh and Ims' parents discourage them from sharing meals and beds, as in sleepover activities, with friends of different religions.

"Since I was a kid, I remember from my elementary school days that my parents always asked about my friends like what ethnic group does he/she come from? What is his/her religion? Something like that. They worried if I got too intimate or eventually dated someone from a different ethnicity or religion." [Wen]

“I don't know, please correct me if I'm wrong. There is a hadith or verse saying that we cannot drink from the same glass as someone of a different faith. Somebody reminded me about that. Also, if we hang out with friends from a different religion, we are not allowed to sleep over or share a bed with them." [Muh] 
"Actually, my parents also told me something similar. There is a perception that non-Muslims usually pet dogs and eat pork that is not kosher to Muslims, and that it might contaminate their living space and cooking or eating utensils." [Ims]

The next level of exclusion is language, which Is reported by Ric and Fan. Ric has experienced segregation in school because he and his peers use the Hokkien language, their mother-tongue, as daily conversational language. He has stated that language may not create a conflict between the IndonesianChinese descendants and the local Bataknese group, but it definitely segregates and limits contact as the local Bataknese group members do not speak Hokkien. According to Ric, the sense of 'us' and 'them' is strongly established. Fan has also mentioned that she feels excluded whenever there is a community gathering. Being an Indonesian-Chinese descendant who lives amongst the majority group of Javanese Muslims, she feels that she is not included in the conversation because they usually speak Javanese.

"Perhaps it's the language. In Medan, most of us, Indonesian-Chinese descendants speak Hokkien. Those who are not IndonesianChinese descendants speak bahasa Indonesia. At home, we speak Hokkien with our parents and family. So, it is our mother tongue. So, when we speak bahasa Indonesia, our dialect will sound different. However, in Jakarta, we speak bahasa Indonesia. That might be the difference." [Ric]

"Religious tolerance, OK. But I can feel it during community gatherings. Mostly my neighbors are Javanese, so during gatherings they will get together amongst themselves and speak in Javanese. My family and I are not Javanese, and we feel left out because we don't speak the language and don't understand what they are talking about. That's how I feel discriminated." [Fan]

Political ideology has become a point of exclusion for Far as she and her family have experienced discriminative treatment for supporting a different presidential candidate than the majority of the people in her neighborhood. She feels very disappointed and betrayed.

"My family has always been very outspoken about our support for a particular presidential candidate, and apparently our choice is very different from the majority of the people in the neighborhood. Hence, we experience hardships when we try to find out the status of our voting registry. We found out that due to our different choice, they were almost successful in sabotaging our voting registry, but we persisted to fight for our rights and finally were able to get the registry. However, I felt that my rights were violated and got very disappointed. My own people failed me." [Far]

The next is religious attire. Post Jakarta's former governor, Basuki Tjahaja Purnama's, famously known as Ahok, blasphemy case, the 2017 gubernatorial election atmosphere is heated. As part of the Muslim majority group who lives in an Indonesian-Chinese descendant-dominated neighborhood, Aly feels the pressure of prejudice on voting day. As she and her family enter the premise of the voting booths with their daily hijab attire, they feel how people look at them differently.

\begin{abstract}
"So, my mom, my sister, my house assistant, and I were wearing our hijabs to the voting booth. It's our daily regular clothing, basically. The voting booth was located in a private Christian school. As we entered the premise, we could see that the majority of the Indonesian-Chinese descendants who were also casting their votes stared at us. For us, it felt really uncomfortable as we could feel how cynical they looked. It was as if they were saying that we must have voted for the governor candidate of the same candidate after the alleged-blasphemy case." [Aly]
\end{abstract}

An important thing to highlight here is the fact that the hijab is not only associated with a particular religion but is also a political signature in Indonesia. This is especially true when perceived negatively by the minority groups as being tendentious towards certain political ideologies.

Another challenge in inclusivity expands to the religious lifestyle of being a vegetarian, as exercised by some Hindus. When a devoted Hindu friend wants to practice vegetarianism, it becomes a challenge for some people in the peer group to accommodate the person, especially when doing social activities together.

"One of my classmates is a practicing Hindu and a vegetarian. So, whenever we go out to eat, we need to consider her diet as well. One of my other friends feels like it's a lot of effort to accommodate her, while I see it as a good exercise to create an inclusive environment, instead of being a burden." [Lev]

Having contact and engaging in intimate social contacts, such as friendships, with people from different groups can also contribute to forms of exclusion, especially when contact is made with members of perceived enemies and/or rival groups. Ims has reported how he has been called out by his old Minangese friends on how he socializes with and befriended Indonesian-Chinese descendants who are perceived as old rivals.

"Several times when we hanged out, my friends would call me out and say that I liked to befriend 
Indonesian-Chinese descendants, as if I was doing something negative." [Ims]

As these points of exclusion emerged from the respondents, it is then important to take a further look into these factors and to what extent each of these points can set groups apart and increase prejudices.

The respondents of the research come from different groups that represented majority and minority religions as well as ethnicities in Indonesia. Living in a diverse and religious nation like Indonesia gives them direct exposure and contact with members of different groups. Ideally, this provides them with vast opportunities to explore the rich cultures and diversity of Indonesian ethnicities, religions, languages, and others. However, under the current circumstances of the heated political atmosphere that enables conflicts through identity politics, people of different groups feel the need to protect their own identities and groups. The need to protect one's identity and the group is not without reason. The respondents all have stereotypical and prejudicial pre-notions transferred to them from their families and communities through the generations. As Bahns (2017) stated, people will then look at members of different groups as perceived threats so that they can justify their prejudices.

From the findings, the respondents have reported how they are educated and directed to be able to identify and categorize themselves as members of certain groups, where identification and selfcategorization work both ways. Some are internalized by family members and communities, and some are identified by the respondents themselves, such as the idea of openness to differences and non-religiosity. The self-categorization process not only includes factors that can be identified as or strengthen the collective identity but also excludes factors that are deemed to segregate. The findings reveal that the respondents perceived various factors as points of exclusion that comprised ethnicities, religions, language, political ideology, religious attire, religious lifestyle, and contact with members of different groups. Some of the respondents have reported a hierarchy of these factors contributing to exclusions and the decisionmaking process. In the context of engaging in intimate social relationships, such as marriage, for those who are Indonesian-Chinese descendants, ethnicity is prioritized for a spouse. Religion comes next, at a level that is tolerable although still discouraged.

From the majority of respondents' perspectives, the most dominant points of exclusion are religion, and ethnicity comes next. As reported by some of the majority group respondents, restrictions are followed when they interact with people of different religious groups. If the context already offers a homogenous community, contact with members of different ethnic groups, particularly Indonesian-Chinese descendants, is questioned and challenged. As noted by the respondents of the majority groups, when they exercise openness to counter prejudice (Halperin \& Bar-Tal, 2011) and connect with members of different groups, they are perceived as one of them. In contrast to the claim on how extended contact, knowing that an in-group member has a positive and close relationship with members of different groups can reduce bias and prejudice, respondents of the majority groups have experienced otherwise (Wright et al., 1997). The respondents have reported how the in-group perceived them differently for engaging in contact with members of different groups, particularly of different ethnicities, such as Indonesian-Chinese descendants.

Conditional tolerance is reported by the respondents of both groups. They are allowed to contact members of different groups, be it religion and/or ethnicities, as long as it does not move towards the direction of long-term, intimate, and committed relationships. In addition to religious, ethnic, and political-ideological differences that are commonly recognized as triggers to prejudices and discriminative behavior, several other factors emerged from the data that also display potential exclusion. Factors like language and dialects, religious attire and lifestyle, and exposure to members of different groups resulted in negative contact and/or contexts.

The inherited stereotypes and prejudices offer limited complexity to the development of social identity. Hence, individuals self-categorize themselves is in less-diverse dimensions, which leads to fewer shared values with others. Fewer shared values with others will not help individuals develop empathy and an understanding of common grounds that they potentially share with members of different groups. Consequently, when people do not find many things in common and are unfamiliar with others who are different from them, they will perceive those differences as threatening.

The points of exclusion emerging from the data show religious and non-religious factors. Some of the points, such as religion, religious attire, and religious lifestyle, are religious-based reasons why people display exclusion towards others. While the other non-religious-based factors like language, political ideology, ethnicity, and having friends of different groups are more societal aspects. Nevertheless, in Indonesia, political ideology can also be considered as being intertwined with religious ideology. Future research might benefit from investigating whether these exclusion points can be applied differently to people, whether they are religious or not.

As the abovementioned explanation stated, the points of exclusion are derived from an individual's self-categorization and identification of others based on similarities and/or dissimilarities and categorized others as part of their in-group or outgroup. It will be worth exploring further whether these points of exclusion are equally contributing factors or if there is a hierarchy to exclusion and induced greater perceived threats from different groups. Despite the fact that most of the respondents are directed into a similar self-categorization mechanism with their parents, relatives, and elderly generations, they have reported that they developed their own self-categorization. 
Their openness and willingness to engage in contact and counter prejudice with members of different groups shift their perceptions of threats and generate a new understanding of tolerance and inclusivity.

\section{CONCLUSIONS}

Spurred by identity politics, Indonesia is faced with rising intolerance. Inherited stereotypes and prejudices are putting the nation in a challenging position, while measures to promote tolerance and inclusivity are not in a compatible magnitude. The respondents of the research have reported how they have been exposed to negative images incepted by their parents and relatives since a very early age. Parents would literally investigate their children's friends' religious and ethnic backgrounds and advise their children not to engage in intimate social contact with members of different groups. This practice is sustained due to the perceived threats collectively shared through the generations.

As reflected in the research, the respondents have reported that despite their upbringing being heavily influenced by transferred stereotypes and prejudices, they embrace exposure to different group members and see it as an opportunity to counter their own prejudices. It is not without challenges, for some of the experienced contacts are negative, and yet, it helps them to explore how to tolerate and accept differences better. Those who come from a homogenous background also experience being questioned and challenged about their openness to diversity. Although the extended contact theory by Wright has stated that having friends who are in contact with members of different groups might reduce prejudice, the respondents of the research reported differently.

The research also highlights the points of exclusion addressed by the respondents. The recurring points of exclusion that emerged from the data analysis cover the religious and non-religious based factors. It is consistent research that stated how people with high and low religious beliefs display prejudices towards people who are different from them. Whether the respondents categorize themselves as religious or not, they are exposed to stereotypes and prejudices either way. Those who do not consider themselves as being religious expressed their prejudices through non-religious points of exclusion.

Despite the findings that are able to identify points of social exclusions among youths of diverse religions, the research could benefit from a larger pool of respondents. Future research can direct their attention towards how points of social exclusion may potentially develop (or not) towards more discriminative and intolerant behaviors. The identification of these points of exclusion in such a diverse nation like Indonesia will contribute to measures taken to promote tolerance and inclusivity. As inherited stereotypes and prejudices are inevitable, further research could also benefit from understanding how to counter these values through different relevant mediums, such as education, social media, dialogues, et cetera. Policies can be devised to investigate how national identity is integrated with formal education and whether the current curriculum promotes it. If the openness exercised by the respondents can be introduced in the primary education pillars, the nation might have more champions of tolerance and inclusivity in the future.

\section{REFERENCES}

Bahns, A. (2017). Threat as justification of prejudice. Group Procesesses \& Intergroup Relations, 20(1), 52-74. https://doi.org/10.1177\%2F1368430215591042.

Barberá, P., Jost, J. T., Nagler, J., Tucker, J. A., \& Bonneau, R. (2015). Tweeting from left to right: Is online political communication more than an echo chamber? Psychological Science, 26(10), 15311542. https://doi.org/10.1177/0956797615594620.

Bos, K. V. D., Poortvliet, P. M., Maas, M., Miedema, J., \& Ham, E. V. D. (2005). An enquiry concerning the principles of cultural norms and values: The impact of uncertainty and mortality salience on reactions to violations and bolstering of cultural worldviews. Journal of Experimental Social Psychology, 41(2), 91-113. https://doi.org/10.1016/j.jesp.2004.06.001.

Brandt, M. J. (2017). Predicting ideological prejudice. Psychological Science, 28(6), 713-722. https://doi. org/10.1177/0956797617693004.

Brandt, M. J., \& Reyna, C. (2010). The role of prejudice and the need for closure in religious fundamentalism. Personality and Social Psychology Bulletin, 36(5), 715-725. https://doi. org/10.1177/0146167210366306.

Brandt, M. J., \& Van Tongeren, D. R. (2017). People both high and low on religious fundamentalism are prejudiced toward dissimilar groups. Journal of Personality and Social Psychology, 112(1), 76-97. https://doi.org/10.1037/pspp0000076.

Braun, V., \& Clarke, V. (2006). Using thematic analysis in psychology. Qualitative Research in Psychology, 3(2), 77-101. https://doi. org/10.1191/1478088706qp063oa.

Center for Strategic and International Studies (CSIS). (2017). Ada apa dengan milenial? Orientasi sosial, ekonomi, dan politik. Retrieved from https://www. csis.or.id/uploaded_file/event/ada_apa_dengan_ milenial____paparan_survei_nasional_csis_ mengenai_orientasi_ekonomi_sosial_dan_politik_generasi_milenial_indonesia_notulen.pdf.

Chowdhury, S. M., Jeon, J. Y., \& Ramalingam, A. (2016). Identity and group conflict. European Economic Review, 90, 107-121. https://doi.org/10.1016/j. euroecorev.2016.02.003.

Fleischmann, F., Phalet, K., \& Swyngedouw, M. (2013). Dual identity under threat: When and how do turkish and moroccan minorities engage in politics? Zeitschrift Fur Psychologie / Journal of Psychology, 
221(4), 214-222. https://doi.org/10.1027/21512604/a000151.

Ginges, J., Hansen, I., \& Norenzayan, A. (2009). Religion and support for suicide attacks. Psychological Science, 20(2), 224-230. https://doi.org/10.1111/ j.1467-9280.2009.02270.x.

Halperin, E., \& Bar-Tal, D. (2011). Socio-psychological barriers peace making: An empirical examination within the Israeli Jewish society. Journal of Peace Research, 48(5), 637-651. https://doi. org/10.1177/0022343311412642.

Hogg, M. A., Abrams, D., \& Brewer, M. B. (2017). Social identity: The role of self in group processes and intergroup relations. Group Processes and Intergroup Relations, 20(5), 570-581. https://doi. org/10.1177/1368430217690909.

Hogg, M. A., Abrams, D., Otten, S., \& Hinkle, S. (2004). The social identity perspective. Small Group Research, 35(3), 246-276. https://doi. org/10.1177/1046496404263424.

Hogg, M. A., Kruglanski, A., \& Bos, K. (2013). Uncertainty and the roots of extremism. Journal of Social Issues, 69(3), 407-418. https://doi.org/10.1111/josi.12021.

Hornsey, M. J. (2008). Social identity theory and selfcategorization theory: A historical review. Social and Personality Psychology Compass, 2(1), 204-222. https://doi.org/10.1111/j.1751-9004.2007.00066.x.

Huddy, L. (2015). Group identity and political cohesion. In Emerging Trends in the Social and Behavioral Sciences. New Jersey: John Wiley \& Sons, Inc. https://doi.org/10.1002/9781118900772.etrds0155.

Hunsberger, B., \& Jackson, L. M. (2005). Religion, meaning, and prejudice. Journal of Social Issues, 61(4), 807-826. https://doi.org/10.1111/j.15404560.2005.00433.x.

Jacks, J. Z., \& Cameron, K. A. (2003). Strategies for resisting persuasion. Basic and Applied Social Psychology, 25(2), 145-161. https://doi.org/10.1207/ s15324834basp2502_5.

Jost, J. T. (2006). The end of the end of ideology. American Psychologist, 61(7), 651-670. https://doi. org/10.1037/0003-066X.61.7.651.

Jost, J. T., Glaser, J., Kruglanski, A. W., \& Sulloway, F. J. (2003). Political conservatism as motivated social cognition. Psychological Bulletin, 129(3), 339-375. https://doi.org/10.1037/0033-2909.129.3.339.

Kruglanski, A. W., Pierro, A., Mannetti, L., De Grada, E. (2006). Groups as epistemic providers: Need for closure and the unfolding of group-centrism. Psychological Review, 113(1), 84-100. https://doi. org/10.1037/0033-295X.113.1.84.

McCoy, M. E. (2013). Purifying Islam in post-authoritarian Indonesia: Corporatist metaphors and the rise of religious intolerance. Rhetoric and Public Affairs, 16(2), 275-315.

Menchik, J. (2014). Productive intolerance: Godly nationalism in Indonesia. Comperative Studies in Society and History, 56(3), 591-621. https://doi. org/10.1017/S0010417514000267.
Merrilees, C. E., Cairns, E., Taylor, L. K., Goeke-Morey, M. C., Shirlow, P., \& Cummings, E. M. (2013). Social identity and youth aggressive and delinquent behaviors in a context of political violence. Political Psychology, 34(5), 695-711. https://doi.org/10.1111/ pops. 12030 .

Onorato, R. S., \& Turner, J. C. (2004). Fluidity in the selfconcept: The shift from personal to social identity. European Journal of Social Psychology, 34(3), 257278. https://doi.org/10.1002/ejsp.195.

PPIM-UIN (Pusat Pengkajian Islam dan Masyarakat-UIN Syarif Hidayatullah). (2017). 'Api dalam Sekam' keberagaman Muslim gen z: Survei nasional tentang keberagamaan di sekolah dan universitas di Indonesia. Retrieved from https://conveyindonesia. com/wp-content/uploads/2019/04/Survey-NasionalKeberagamaan-GenZ.pdf.

Saucier, D. A., \& Webster, R. J. (2010). Social vigilantism: Measuring individual differences in belief superiority and resistance to persuasion. Personality and Social Psychology Bulletin, 36(1), 19-32. https://doi. org/10.1177/0146167209346170.

Scheufele, D. A., Corley, E. A., Shih, T. J., Dalrymple, K. E., \& Ho, S. S. (2009). Religious beliefs and public attitudes toward nanotechnology in Europe and the United States. Nature Nanotechnology, 4, 91-94. https://doi.org/10.1038/nnano.2008.361.

Skitka, L. J. (2010). The psychology of moral conviction. Social and Personality Psychology Compass, 4(4), 267-281. https://psycnet.apa.org/doi/10.1111/ j.1751-9004.2010.00254.x.

Stephan, W. G., \& Stephan, C. W. (1985). Intergroup Anxiety. Journal of Social Issues, 41(3), 157-175. https://doi. org/10.1111/j.1540-4560.1985.tb01134.x.

Stephan, W. G., Stephan, C. W., \& Gudykunst, W. B. (1999). Anxiety in intergroup relations: A comparison of anxiety/uncertainty management theory and integrated threat theory. International Journal of Intercultural Relations, 23(4), 613-628. https://doi. org/10.1016/S0147-1767(99)00012-7.

Stoeckel, F. (2016). Contact and community: The role of social interactions for a political identity. Political Psychology, 37(3), 431-442. https://doi.org/10.1111/ pops. 12295.

Voci, A., Hewstone, M., Swart, H., \& Veneziani, C. A. (2015). Refining the association between intergroup contact and intergroup forgiveness in Northern Ireland: Type of contact, prior conflict experience, and group identification. Group Processes and Intergroup Relations, 18(5), 589-608. https://doi. org/10.1177/1368430215577001.

Wright, S. C., Aron, A., McLaughlin-Volpe, T., \& Ropp, S. A. (1997). The extended contact effect: Knowledge of cross-group friendships and prejudice. Journal of Personality and Social Psychology, 73(1), 73-90. https://doi.org/10.1037/0022-3514.73.1.73. 